\title{
Pulmonary and central nervous system infiltration of chronic lymphocytic leukemia with concomitant diffuse large B-cell lymphoma: Case report and review of literature
}

Saulo F. D. Batista, ${ }^{1}$ Karina V. de Melo, ${ }^{2}$ Patricia Horn, ${ }^{2}$ Vinicius da C. Lisboa, ${ }^{3}$ Ana Sheila Cypriano, ${ }^{3}$ Andrea Pires, ${ }^{4}$ Marilza de M. Ribeiro-Carvalho, ${ }^{3}$ Fábio Santiago, ${ }^{3 *}$ Maria Helena F. O. de Souza ${ }^{3,5}$

\begin{abstract}
Introduction: Diffuse large B-cell lymphoma (DLBCL) and chronic lymphoid leukemia (CLL) are lymphoproliferative diseases of B lymphocytes. Objective: To describe the concomitance of diseases with pulmonary and CNS involvement. Clinical case: A 67-year-old patient with DLBCL and CLL obtained partial remission of the diseases after six cycles of standard combined chemotherapy. Relapse of CLL (del17p; TP53+) occurred after 22 months, becoming refractory to a new treatment. Monoclonal B lymphocyte infiltration was found in the cerebrospinal fluid and bronchoalveolar lavage, leading to death due to respiratory failure. Conclusion: The unfavorable outcome shows a rare and serious complication in the concomitance of these diseases.
\end{abstract}

Keywords: Chronic lymphoid leukemia (CLL), Diffuse large B-cell lymphoma (DLBCL), Central Nervous System infiltration; Pulmonary infiltration.

\section{Resumo}

Infiltração pulmonar e do sistema nervoso central da leucemia linfocítica crônica com Linfoma difuso de grandes células B concomitantes: relato de caso e revisão da literatura

Introdução: Linfoma difuso de grandes células B (LDGCB) e leucemia linfoide crônica (LLC) são doenças linfoproliferativas dos linfócitos B. Objetivo:Descrever concomitância das doenças com acometimento pulmonar e do Sistema Nervoso Central. Caso clínico: Paciente de 67 anos, com LDGCB e LLC, obteve remissão parcial das doenças após seis ciclos de quimioterapia combinada padrão. Evoluiu após 22 meses com recidiva da LLC (del 17p TP53+), tornando-se refratário a novo tratamento. Foi constatada infiltração de linfócitos B monoclonais no liquor e nolavado broncoalveolar, levando-oao óbito por insuficiência respiratória. Conclusão: O desfecho desfavorável evidencia como uma rara e grave complicação na concomitância dessas doenças.

Descritores: Leucemia linfoide crônica (LLC); Linfoma difuso de grandes células B (LCGCB); Infiltração de Sistema Nervoso Central; Infiltração pulmonar.
1. Medical Clinic Service, Pedro Ernesto University Hospital, Rio de Janeiro State University (UERJ). Rio de Janeiro, Brazil.

2. Hematology Service, Pedro Ernesto University Hospital, Rio de Janeiro State University (UERJ). Rio de Janeiro, Brazil.

3. Department of General Pathology, Faculty of Medical Sciences. Rio de Janeiro State University (UERJ), Rio de Janeiro, Brazil.

4. Fonte Medicina Diagnóstica Laboratory. Niterói, Brazil.

5. Postgraduate Program in Medical Sciences (PGCM), Rio de Janeiro State University (UERJ). Rio de Janeiro, Brazil.

*Correspondence address:

Departamento de Patologia Geral e Laboratórios

Avenida Professor Manoel de Abreu, 444, 4ㅇandar

Rio de Janeiro, RJ, Brasil.

CEP: 20550-170.

E-mail: dr.fabiosantiago@gmail.com

BJHBS, Rio de Janeiro, 2020;19(2):124-129

Received on 08/05/2020. Approved on 30/06/2020.

\section{Resumen}

Infiltración pulmonar y del sistema nervioso central de leucemia linfocítica crónica con Linfoma difuso de células B grandes concomitante: reporte de un caso y revisión de la literatura

Introduction: El linfoma difuso de células B grandes (LDGCB) y la leucemia linfoide crónica (CLL) son enfermedades linfoproliferativas comunes. Objetivo: Describir la concomitancia de ambos con compromiso pulmonar y del líquido cefalorraquídeo. Caso clínico: El paciente con LDGCB y CLL fue tratado con 6 ciclos de RCHOP (ciclofosfamida, doxorrubicina, vincristina, prednisona y rituximab), obteniendo remisión. La recaída de la CLL refractaria al tratamiento ocurrió y FISH mostró del 17p TP53+.El paciente desarrolló afectación extramedular de CLL y evolucionó a insuficiencia respiratoria y muerte. Conclusión: La concomitancia de estas dos neoplasias malignas con afectación pulmonar y del SNC es un evento raro.

Palabras clave: Linfoma difuso de células B grandes (LLC); Linfoma difuso de células B grandes (LCGCB); Infiltración del Sistema Nervioso Central; Infiltración pulmonar. 


\section{Introduction}

Diffuse large B-cell lymphoma (DLBCL) and B-cell chronic lymphocytic leukemia (B-CLL) are the most common types of lymphoproliferative diseases in elderly people. ${ }^{1}$ The DLBCL is the most common subtype of non-Hodgkin lymphoma (NHL) characterized by large or medium lymphoid cells with B-cell markers growing in a diffuse rather than nodular pattern. It corresponds to a biologically heterogeneous family of diseases and it is subdivided into morphological, biological, and clinical studies. The neoplastic cells express CD19, CD20, CD22, CD79a, and Ki-67 (with a high proliferation index, more than $40 \%)^{1,2} \mathrm{~B}$-CLL is characterized by proliferation and accumulation of monoclonal Blymphocytes, expressing CD5, CD20, and CD23 molecules in the cells of blood, bone marrow, and lymphoid organs. The clinical presentation is insidious and frequently the diagnosis is made by an incidental finding of lymphocytosis in a complete blood count requested by another cause, followed by lymphadenomegaly, B symptoms (fever, night sweats, weight loss, and fatigue) and cytopenias such as anemia, thrombocytopenia, and neutropenia due to bone marrow infiltration. ${ }^{3}$ Traditionally, CLL has been stratified by RAI and Binet staging systems that take into account symptoms, involvement of lymphoid tissues, physical examination, imaging, and laboratory results, the Lugano Modification of Ann Arbor staging system depending on the extension of nodal and extranodal disease, cytogentics, showing mutations on Bruton Tyrosine Kinase and phospholipase Cy2 genes, deletion of 17P and TP53 mutation, NOTCH1, SB3B1 and BIRC3 gene mutations, and, over flow cytometry, indicating the status of IGHV mutational, CD49d, CD38 and ZAP-70 available or not to indicate treatment.,

Many complications can be found that interfere with the prognosis of CLL. Most common among them are infections, autoimmune cytopenias, and transformation into high-grade lymphoma diffuse large B-cell lymphoma (Richter's syndrome). ${ }^{3}$ Extramedullary manifestations are considered rarer and are defined as any presentation of CLL outside of the blood or bone marrow, occurring with or without the presence of systemic CLL. According to the Ratterman and colleagues study (2014), central nervous system, skin, gastrointestinal, and genitourinary/ gynecology infiltrations are more frequent, whereas lung, ocular, and other sites, as shown in Figure $1 .^{6}$ Here we describe a case of DLBCL and CLL concomitance in which there was relapse with refractory CLL after 22 months post-treatment and progression to simultaneous leptomeningeal and lung involvement.
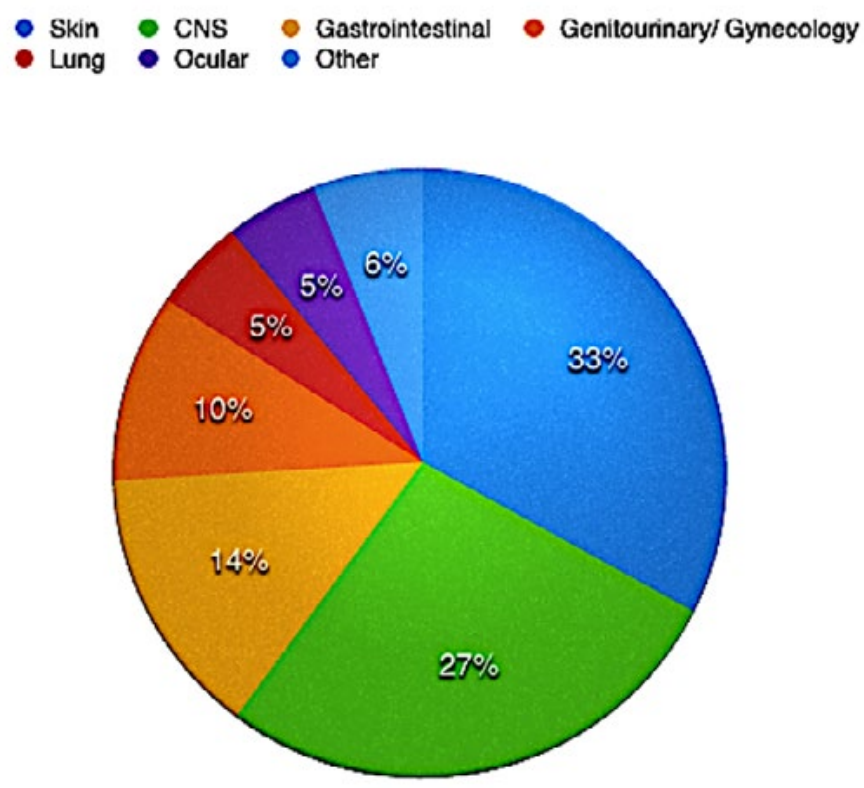

Figure 1. The most commonly reported extramedullary manifestations of chronic lymphocytic leukemia ${ }^{6}$ 


\section{Review article}

\section{Case Report}

A 67-year-old man was admitted to the HUPE/ UERJ in December 2013, presenting generalized lymph node enlargement in cervical, axillary, and inguinal chains without symptoms. The admission blood exams revealed normal values (hematocrit 38\%; hemoglobin $13.5 \mathrm{~g} / \mathrm{dL} ; \mathrm{WBC} 5460$ cell $/ \mathrm{mm}^{3}$; lymphocytes 2620 cell/ $\mathrm{mm}^{3}$; platelets $172,000 / \mathrm{mm}^{3}$ and negative serologies (HIV, HCV, HBV, and CMV).

A cervical ganglion biopsy was performed and the immunohistochemical analysis was compatible with DLBCL (CD20, Bcl2, CD10 positives; CD3 negative; and Ki-67 labelling index > 40\% (Figure 2, a, b and c). In March 2014, a bone marrow biopsy (BMB) revealed infiltration of small B-cell CD20 positive (Figure $2 \mathrm{~d}$ ). In July 2014, the remission was obtained after RCHOP treatment ( 6 cycles) and no more neoplastic cells were detected in the bone marrow analysis.

The patient maintained regular hematological follow-up until April 2016, when lymphocytosis and generalized lymph node enlargement were observed (WBC 44,900 cell $/ \mathrm{mm}^{3}$, with 70\% lymphocytes). The immunophenotypic analysis revealed a monoclonal B lymphocyte infiltration (87\%) in the bone marrow biopsy, compatible with LLC recurrence (Figure $3 \mathrm{a}$ and $\mathrm{b}$ ). Soon afterwards a new chemotherapy treatment was started with five cycles of fludarabine and cyclophosphamide, without clinical success. The treatment was suspended after the ninth month due to many complications, such as bleeding and febrile neutropenia (hematocrit 13\%; hemoglobin $4.2 \mathrm{~g} / \mathrm{dL}$; WBC 945 cell $/ \mathrm{mm}^{3}$; platelets $172,000 / \mathrm{mm}^{3}$ ).

Fluorescent in Situ Hybridization (FISH) analysis was performed with a poor prognostic result (del 17p; TP53+). The thorax tomography evidenced a lung nodule and pleural effusion with a positive galactomannan blood test, suggesting opportunistic infection by aspergillus. Despite antibiotic therapy (meropenem and voriconazole), the patient progressed with worsening of the general condition, maintenance of daily fever (with temperatures up to $39^{\circ} \mathrm{C}$ ), dyspnea, severe holocranial headache, and visual turbidity. Due to this clinical condition, bronchoscopy and lumbar puncture were performed for BAL and

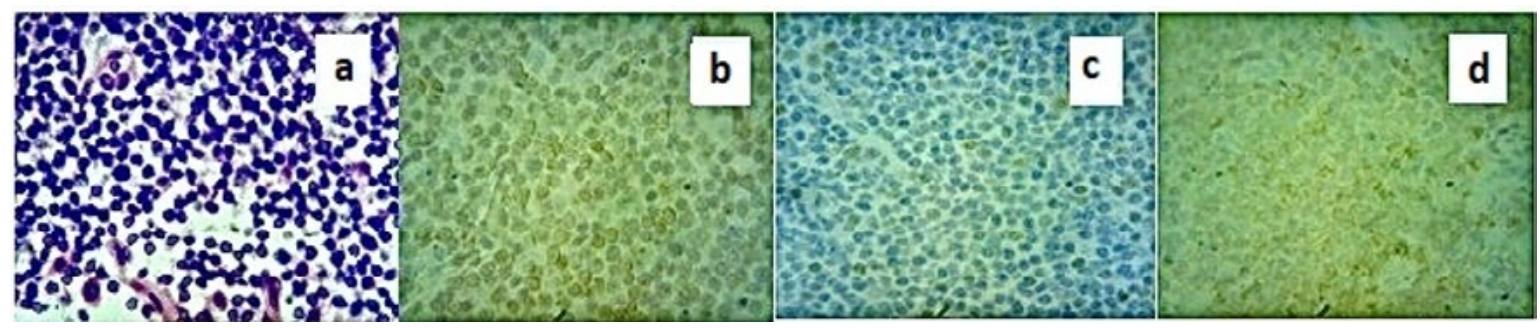

Figure 2. A cervical ganglion biopsy was performed and the immunohistochemical analysis was compatible with DLBCL (Figure $1 \mathrm{HE}, \mathrm{CD} 20$, Bcl2; (Figure 1, a, b, and c). In March 2014, a bone marrow biopsy (BMB) revealed infiltration of small B cells (CD20 positive) (Figure 1, d)

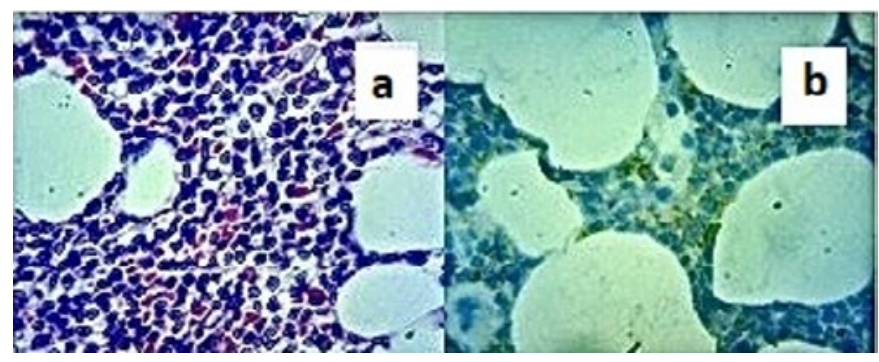

Figure 3. HE and the immunophenotypic (CD20) analysis revealed B lymphocyte infiltration $(87 \%)$ in the bone marrow biopsy, compatible with LLC recurrence (Figure 2, a and b) 
LCR investigation. Note that BAL and LLC cultures for microorganisms were negative; however, the immunophenotypic studies evidenced a massive monoclonal B-cell infiltration in both organs (Figure $4 \mathrm{a}$ and b). Thus, the ibrutinib treatment was immediately started, but pulmonary and renal conditions worsened evolving to death.

\section{Discussion}

Two or more synchronous hematologic neoplasms in the same patient are often observed in clinical practice. In our experience we have already described one case involving acute myeloid leukemia (AML) and chronic lymphoid leukemia (CLL) ${ }^{8}$ Although DLBCL and CLL are the most common lymphoproliferative diseases in this age group, this concomitant or metachronous presentation is rare with few cases described..$^{9,10}$ One possibility is that this patient had a previous CLL with evolution to Ritcher syndrome and transformation to DLBCL. This patient has presented DLBCL diagnosed in January 2014 and CLL diagnosed in March 2014, respectively. This short time between them suggests that both can be considered concomitant B-cell neoplasms. ${ }^{11}$ The review of the ganglion sample at diagnosis was found to be CD5 positive. This reinforces the hypothesis of concomitance of DLBCL and CLL since the patient did not have significant lymphocytosis at this time (less than $>5$ 109/L). In our case, DLBCL was firstly diagnosed by histopathological study while small cell lymphoma went unnoticed and was only diagnosed two months later in a bone marrow biopsy. At that time the hemogram revealed lymphocytes $2.6 \times 109$, so the possible diagnosis was monoclonal
B lymphocytosis or CLL.12 Richter's syndrome (RS) is considered a rare complication in patients with CLL. ${ }^{13}$ Its prognosis is unfavorable because the disease transforms into diffuse large B-cell lymphoma (DLBCL). Approximately only 5 to $10 \%$ of CLL patients develop this complication during long-term follow-up. Half of these patients develop RS in the absence of any therapy for CLL, suggesting that there is an inherent biological risk for the development of RS in patients independent of CLL therapy.

In this case report there are some aspects that are worthy of note. The patient remained under careful observation for 28 months after being diagnosed as having DLBCL. Twenty-two months after completing R-CHOP-based chemotherapy, the CLL patient relapsed with hyperleukoctosis. According to Brazilian legislation, rituximab cannot be administered in relapsed patients.

Although CLL is classified as a low-grade B-cell malignancy, some patients, like our patient, experienced an aggressive form. This patient had treatment refractoriness characterized by high lymphocyte levels $(>100,000$ cells/mm3) and FISH evidenced del 17p TP53+. TP53 disruption in chronic lymphocytic leukemia (CLL) is a well-established prognostic marker and informs on the appropriate course of treatment for patients. TP53 status is commonly assessed by fluorescence in situ hybridization (FISH) for del (17 p) and Sanger sequencing for TP53 mutations. ${ }^{15,16}$

In addition, our patient developed extra medullary manifestations characterized by neurological and pulmonary involvements. Neurological manifestations in CLL patients can vary from headache, mental confusion, and seizure to neurological deficits. Distinguishing whether neurological symptoms are
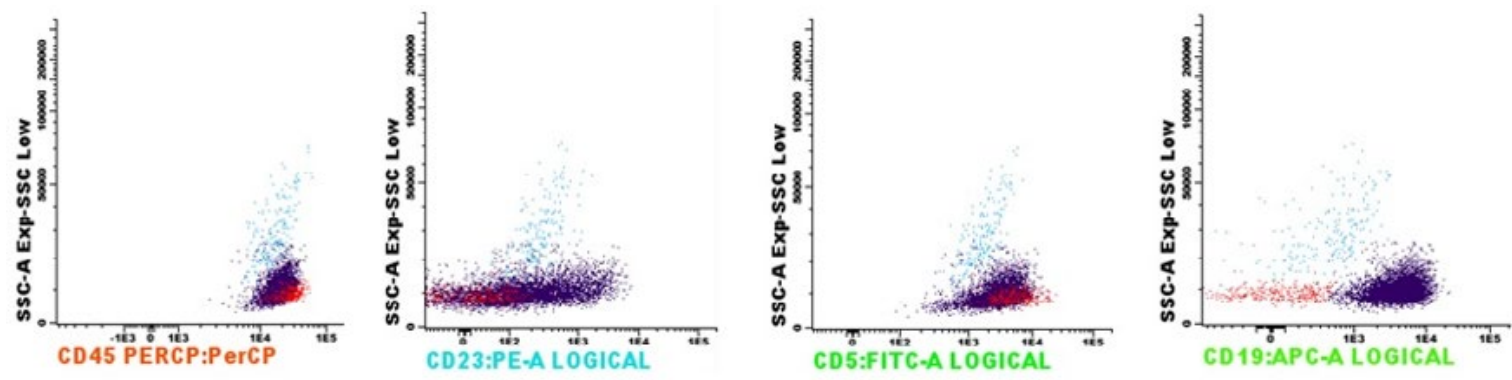

Figure 4. Analysis of CSF performed through immunophenotyping. The following results were found: monocytes $(2.7 \%)$; T lymphocytes $(4.83 \%)$; B lymphocytes $(91.42 \%$ - CD5+/CD23+) 
due to CLL or other etiologies can be challenging, requiring extensive research. ${ }^{17-20}$ Although all symptomatic patients should be initially approached with imaging, magnetic resonance imaging, or cranial and/ or spinal tomography depending on the complaint, the cerebrospinal is considered of great value. Cerebrospinal fluid (CSF) analysis is required and flow cytometry should be requested to distinguish normal from neoplastic lymphocytes. Other tests should also be requested to rule out different causes, such as direct fungal and gram screening, bacterial and fungal culture, and virus screening, especially for herpes and JC virus. Diagnosis is made when there is evidence of CNS involvement by CLL, with no other more likely cause. There is no clear relationship between the stage of the disease and CNS involvement, and all patients should be investigated, regardless of their staging. .7-20 $^{-2}$

In the case discussed, the patient had recent and progressive neurological symptoms (headache and blurred vision), with no solid image on the tomography of the skull or spine. There were numerous cells with CLL-compatible cytometry and phenotyping, with no other causes that could better explain the symptoms. Ibrutinib was chosen, which has shown promising results in the treatment of CLL with CNS involvement. ${ }^{21,}$ ${ }^{22}$ Unfortunately, due to bureaucratic barriers, the drug was started too late and only a single dose was given. During that time the patient developed a poor outcome, tumor lysis syndrome, respiratory failure, and death. Pulmonary complications in patients with leukemia are often due to pneumonia, hemorrhage, edema, and/or drug toxicity. However, there are several causes of pulmonary disease that are directly related to leukemia, including leukemic pulmonary infiltra-

\section{References}

1. Chastain EC, Duncavage EJ. Clinical prognostic biomarkers biomarkers in chronic lymphocytic leukemia and diffuse large B-cell lymphoma.Arch Pathol Lab Med. 2015;139(5): 602-7.

2. Swerdlow SH, Campo E, Pileri SA, et al. Who Classification of tumours of Haematopoietic and lymphoid Tissues. IARC, Lyon 2017.

3. Hallek M, Shanafelt TD, Eichhorst B. Chronic lymphocytic leukaemia. Lancet. 2018;391(10129):1524-1537.

4. Rai KR, Sawitsky A, Cronkite EP, et al. Clinical staging of chronic lymphocytic leukemia. Blood. 1975;46(2):219-234.

5. NCCN Clinical Practice Guidelines in Oncology. Chronic lymphocytic leukemia/small lymphocytic lymphoma, version 4.2020. tion, pulmonary leukostasis, leukemic cell lysis, and hyperleukocytic reaction. In the case of our patient, the first hypothesis suggested was aspergillus with positive serum galactomannan (GM) measurements. The treatment with antibiotics had no benefit.

Leukemic pulmonary infiltration occurs most commonly in the terminal stage of the disease. Autopsy studies have found leukemic pulmonary infiltration in more than $25 \%$ of patients with leukemia. ${ }^{23}$

In conclusion, CSF and BAL cytology examinations are considered the "gold standard" for diagnoses of EM involvement of CLL. Also, CLL lymphocytes cannot be distinguished from reactive lymphocytes by morphology alone. For this reason, flow cytometry is a useful tool for distinguishing the lymphocytes. Flow cytometry immunophenotyping (FCI) is an objective and rapid method of qualitative and quantitative analysis of cell suspensions. It can detect small populations of tumor cells with aberrant surface-marker expression through multicolor and multiparameter analysis. FCI is considered to be two to three times more sensitive than cytology in detecting CSF and lung malignant infiltration. There is little consolidated information on prognostic factors or guidelines for the CNS approach to pulmonary and CNS involvement. Multiple treatments with different mechanisms of action have been tested with varying response rates and response maintenance time. Among the few existing studies, ibrutinib monotherapy has been showing good results, being one of the drugs of choice for treatment. Unfortunately, in the present case, the treatment was started too late due to bureaucratic difficulties in acquiring the drug.
National Comprehensive Cancer Network website. Nccn.org/ professionals/physician_gls/pdf/cll.pdf. Accessed April 22, 2020.

6. Ratterman M, Kruczek K, Sulo S, et al. Extramedullary chronic lymphocytic leukemia: systematic analysis of cases reported between 1975 and 2012. Leuk Res. 2014;(38):299-303.

7. Abuelgasim KA, Rehan $\mathrm{H}$, Alsubaie $\mathrm{M}$, et al. Coexistence of chronic myeloid leukemia and diffuse large B-cell lymphoma with antecedent chronic lymphocytic leukemia: a case report and review of the literature. J Med Case Rep. 2018;(12):641.

8. Ornellas MHF, Fernandez TS, Diamond HR, et al. Cytogenetic and immunophenotypic evidence of independent clonal origins of concomitant chronic lymphocytic leukaemia and acute myeloid leukaemia. European Journal of Haematology. 2001; (66):281-283. 
Saulo F. D. Batista e. cols. • Pulmonary and central nervous system infiltration

9. Langer S, Dass J, Mittal S, et al. Concomitant Presence of CD5-Positive Diffuse Large B-Cell Lymphoma and Monoclonal B Cells with the "CLL Immunophenotype" - Is It Richter's Transformation? Turk J Haematol. 2017;34(2):188-190.

10. Wei Q, Sebastian S, Papavassiliou P, et al. Metachronous/ concomitant B-cell neoplasms with discordant light-chain or heavychain isotype restrictions: evidence of distinct B-cell neoplasms rather than clonal evolutions. Hum Pathol. 2014;(45):20632076

11. Anderson JR, Armitage JO, Weisenburger D. Epidemiology of the non-Hodgkin's lymphomas: Distributions of the major subtypes differ by geographic locations. Annals of Oncology 1998;(9):717-72.

12. Porcu P, Cripe LD, Ng EW, et al. Hyperleukocytic leukemias and leukostasis: a review of pathophysiology, clinical presentation and management. Leuk Lymphoma. 2000;39(1-2):1-18.

13. Wąsik-Szczepanek E, Szymczyk A, Szczepanek D. et al. Richter syndrome: rare complication of chronic lymphocytic leukemia or small lymphocytic lymphoma. Adv Clin Exp Med. 2018;27(12):1683-1689.

14. Parikh AS, Shanafelt TD. Risk Factors for Richter Syndrome in Chronic Lymphocytic Leukemia. Curr Hematol Malig Rep. 2014;(9):294-299.

15. Catherwood MA, Gonzalez D, Donaldson D, et al. Relevance of TP53 for CLL diagnostics. J Clin Pathol. 2019;72(5):343-346.

16. Campo E, Cymbalista F, Ghia P, et al. TP53 aberrations in chronic lymphocytic leukemia: an overview of the clini- cal implications of improved diagnostics. Haematologica. 2018;103(12):1956-1968.

17. Strati $P$, Shanafelt TD. Monoclonal B-cell lymphocytosis and early-stage chronic lymphocytic leukemia: diagnosis, natural history, and risk stratification. Blood. 2015 Jul 23;126(4):45462.

18. Strati P, Uhum HJ, Kaulfmann TJ, et al. Prevalence ad Characterisitics Of Central Nervous System Involvement by Chronic Lymphocytic Leukemia. Haematologica. 2016; 4.

19. Lopes da Silva R. Spectrum of neurologic complications in chronic lymphocytic leukemia. Clin Lymphoma Myeloma Leuk. 2012;(12):164-179.

20. Souza SL, Santiago F, Ribeiro-Carvalho M, et al. Leptomeningeal involvement in B-cell chronic lymphocytic leukemia: a case report and review of the literature. BMC Res Notes. 2014;(3)7:645.

21. Wanquet A, Birsen A, Choquet S, at al. Central Nervous System Involvement in Chronic Lymphocytic Leukemia: Diagnosis and Treatment in a Retrospective Cohort of Thirty Patients. American Society of Hematology, 2015; 12(3).

22. Wanquet A, Birsen R, Lemal $R$, et al. Ibrutinib responsive central nervous system involvement in chronic lymphocytic leukemia. Blood. 2016 May 12;127(19):2356-8.

23. Barcos M, Lane W, Gomez GA, et al. An autopsy study of 1206 acute and chronic leukemias (1958 to 1982). Cancer. 1987 Aug $15 ; 60(4): 827-37$. 